\title{
Tipe pola asuh orang tua yang berhubungan dengan perilaku bullying pada pelajar SMP
}

\author{
Anhar Jaya Putra ${ }^{1}$, Teguh Pribadi*, Dhini Easter Yanti² \\ 1Program Studi IImu Keperawatan Fakultas Kedokteran Universitas Malahayati, Bandar Lampung. \\ 2Fakultas Kesehatan Masyarakat Universitas Malahayati, Bandar Lampung. Email: easter@gmail.com \\ Korespondensi Penulis: Teguh Pribadi. *Email: teguh@malahayati.ac.id
}

\section{Abstract \\ Indonesian parenting styles and bullying among junior high school students, Bandar Lampung-Indonesia}

Background: The data base of Child Protection Committee in Indonesia 2011-2014 had been increasing and is ranked at the top of 369 cases reported to Child Protection Committee such as in education enviroment, bullying behaviour among students at the schools was very common. The reason of the student has a bullying behaviour can be from various factors such as parenting styles of their parent.

Purpose: To know the relationship between parenting styles and bullying among junior high school students, in Bandar Lampung-Indonesia

Method: A quantitative research type by using a cross sectional approach. The population were all students of grade VII and VIII at Gajah Mada junior high School in Bandar Lampung, Indonesia, with the sample 153 respondents. Data collection techniques were carried out by questionnaire. The statistical test used by the chi square test.

Results: Most respondents claim uninvolved a school bullying, as much as 111 students (72.5\%). Most of the respondents claim have a democratic parenting styles by their parent as many as 78 respondent $(51.0 \%)$. There is a relationship between parenting styles and bullying among junior high school students,

Bandar Lampung-Indonesia in 2019 with $p$-value $<a(0,000<0.05)$

Conclusion: There is a relationship between parenting styles and bullying among junior high school students, Bandar Lampung-Indonesia. Suggestions for educational institutions, it is hoped that the results of this study can be a means and reference for educators / schools in overcoming the problem of school bullying among junior high school students by informing to the parents to be applying appropriate a parenting style to their children.

\section{Keywords: Parenting styles; Bullying; Junior high school; Students}

Pendahuluan: Kasus bullying menurut KPAI pada tahun 2011-2014 juga semakin meningkat dan menduduki peringkat teratas sebanyak 369 pengaduan kepada KPAl, dalam bidang pendidikan seperi kekerasan di sekolah, diskriminasi terdapat sekitar 1480 kasus. Penyebab seseorang menjadi pelaku "bullying" bisa dari berbagai faktor seperti orang tua yang terlalu memanjakan anaknya.

Tujuan: Diketahui hubungan pola asuh orangtua dengan perilaku bullying pada siswa SMP Gajah Mada Kota Bandar Lampung Tahun 2019.

Metode: Penelitian kuantitatif, menggunakan pendekatan cross sectional. Populasinya seluruh siswa kelas VII dan VIII di SMP Gajah Mada Bandar Lampung pada tahun 2019 yaitu sebanyak 246 orang. Sampel 153 responden. Tehnik pengumpulan data dilakukan dengan kuesioner. Uji statistik yang digunakan adalah uji chi square.

Hasil: Sebagian besar responden mengaku tidak melakukan perilaku bullying yaitu sebanyak 111 orang (72,5\%). Sebagian besar responden mengaku memiliki pola asuh orang tua yang demokratis sebanyak 78 orang $(51,0 \%)$. Terdapat hubungan pola asuh orangtua dengan perilaku bullying pada siswa SMP Gajah Mada Kota Bandar Lampung Tahun 2019 dengan nilai $p$-value $<a(0,000<0,05)$

Simpulan: Ada hubungan pola asuh orangtua dengan perilaku bullying. Saran kepada institusi pendidikan, diharapkan hasil penelitian ini dapat menjadi sarana dan referensi bagi pihak pendidik/ sekolah dalam mengatasi 
Tipe pola asuh orang tua yang berhubungan dengan perilaku bullying pada pelajar SMP

masalah bullying pada remaja dengan memberkan informasi pada oraang tua supaya dapat menerakan pola asuh yang tepat bagi anaknya.

\section{Kata Kunci: Tipe pola asuh; Orang tua; Perilaku bullying; Pelajar SMP}

\section{PENDAHULUAN}

Akhir-akhir ini kasus akibat kekerasan di sekolah makin sering ditemui baik melalui informasi di media cetak maupun yang kita saksikan di layar televisi. Selain tawuran antar pelajar sebenarnya ada bentuk-bentuk perilaku agresif atau kekerasan yang mungkin sudah lama terjadi di sekolah-sekolah, namun tidak mendapat perhatian, bahkan mungkin tdak dianggap sesuatu hal yang serius. Misalnya bentuk intimidasi dari teman-teman atau pemalakan, pengucilan diri dari temanya, sehingga anak jadi malas pergi ke sekolah karena merasa terancam dan takut, sehingga bisa menjadi depresi tahap ringan dan dapat mempengaruhi belajar di kelas (Ehan, 2016).

Bullying dikenal sebagai penindasan dan merupakan segala bentuk penindasan atau kekerasan yang dilakukan dengan sengaja oleh satu atau sekelompok orang yang lebih kuat atau berkuasa terhadap orang lain, bertujuan untuk menyakiti dan dilakukan secara terus menerus. Perilaku Bullying dapat dilakukan dalam berbagai bentuk seperti Bullying berupa tindakan kekerasan fisik, relasional seperti pengucilan atau cibiran, serta segala bentuk tindakan yang dapat menyakiti orang lain dengan sarana media elektronik (Wardhana, 2014).

Salah satu fenomena yang menyita perhatian di dunia pendidikan zaman sekarang adalah kekerasan sekolah yang di lakukan oleh antarsiswa. Maraknya aksi tawuran dan kekerasan (bullying) yang dilakukan oleh siswa di sekolah yang semakin banyak menghiasai deretan berita di halaman media cetak maupun elektronik menjadi bukti telah tercerabutnya nilai-nilai kemanusiaan (Wiyani, 2012).

Data KPAl (Komisi Perlindungan Anak Indonesia) mendata mengenai kasus kekerasan, kekerasan anak dapat terjadi melalui 3 hal, dari orang tua, keluarga, atau orang terdekat seperti teman. Pemantauan KPAl dari tahun 2011 sampai 2014 meningkat dari 2178 kasus pada tahun 2011 hingga 5066 kasus pada tahun 2014. Pemantauan yang dilakukan oleh KPAI menyebutkan jika tahun 2012 sebanyak 91\% anak menjadi korban kekerasan dalam keluarga, $87,6 \%$ di lingkungan sekolah seperti Bullying yang terjadi di sekolah, dan 17,9\% di sekitar lingkungan masyarakat (Setyawan, 2015). Sedangkan kasus Bullying menurut KPAI pada tahun 2011-2014 juga semakin meningkat dan menduduki peringkat teratas sebanyak 369 pengaduan kepada KPAl, dalam bidang pendidikan seperi kekerasan di sekolah, diskriminasi terdapat sekitar 1480 kasus (Saifurrohman, 2016).

Berdasarkan data KPAI Provinsi Lampung dari tahun ke tahun kekerasan terhadap anak mengalami peningkatan jumlah yang relative tinggi mulai dari periode 2007-2008 sebanyak 316 kasus dan mengalami penurunan pada periode 20082010 menjadi 160 kasus dan 57 kasus. Kekerasan terhadap anak kembali meningkat pada periode 2010-2011 sebanyak 416 kasus dan kembali turun pada periode 2011-2012 menjadi 175 kasus akan tetapi kekerasan terhadap anak kembali mengalami peningkatan yang signifikan pada periode 2012-2013 menjadi 702 kasus dan pada periode 2013-2014 menjadi 589 kasus (Setyawan, 2015).

Berdasarkan penelitian sebelumnya oleh Yayasan Semai Jiwa Amini tahun 2008 tentang Bullying di kota besar di Indonesia yaitu Yogyakarta, Surabaya, dan Jakarta tercatat terjadinnya tingkat Bullying sebesar $66,1 \%$ di tingkat sekolah lanjutan pertama (SMP). Bullying dilakukan sesama siswa, tercatat sebesar $41,2 \%$ untuk tingkat SMP dengan kategori tertinggi Bullying psikologi berupa mengucilkan. Peringkat kedua ditempati kekerasan verbal (mengejek) dan terakhir kekerasan fisik (memukul).

Dampak bullying dapat menyebabkan seorang anak yang menjadi korban akan terhambat dalam aktualisasi diri. Bullying tidak memberi rasa aman dan nyaman, sehingga membuat korban takut, terintimidasi, rendah diri, serta merasa tidak berharga, penyesuaian sosial yang buruk di mana korban merasa takut ke sekolah bahkan tidak mau sekolah, menarik diri dalam pergaulan, prestasi akademik menurun karena mengalami kesulitan untuk berkonsentrasi dalam belajar, bahkan

Anhar Jaya Putra', Teguh Pribadi*, Dhini Easter Yanti ${ }^{2}$

'Program Studi llmu Keperawatan Fakultas Kedokteran Universitas Malahayati, Bandar Lampung.

${ }^{2}$ Fakultas Kesehatan Masyarakat Universitas Malahayati, Bandar Lampung. Email: easter@gmail.com

Korespondensi Penulis: Teguh Pribadi. "Email: teguh@malahayati.ac.id 
Tipe pola asuh orang tua yang berhubungan dengan perilaku bullying pada pelajar SMP

keinginan untuk bunuh diri daripada harus menghadapi tekanan-tekanan berupa hinaan dan hukuman (Yayasan Sejiwa Amani, 2008; Fauzi, \& Mamnu'ah, 2017; Apsari, 2013).

Banyak sekali faktor penyebab mengapa seseorang berbuat bullying. Pada umumnya orang melakukann bullying karena merasa tertekan, terancam,terhina, dendam dan sebagainya. Bullying disebabkan oleh korban dari keadaan lingkungan yang membentuk kepribaiannya menjadi agresif dan kurang mampu mengendalikan emosi misalnya lingkungan rumah/keluarga yang tidak harmonis yaitu sering terjadi pertengkaran antara suami istri yang dilakuakn di depan anakanak atau sering terjadi tindak kekerasan yang dilakukan orang tua terhadap anaknya, anak yang terlalu dikekang atau serba dilarang atau anak yang diperlakukan permisif. Faktor sikap orang tua yang terlalu memanjakan anaknya bisa membuat berperilaku bullying, keluarga yang berantakan menyebabkan anak merasa tidak mendapatkan perhatian (Ehan, 2016; Ulfah, Mahmudah \& Ambarwati, 2017; Alawiyah, 2018).

Keluarga merupakan salah satu faktor yang mempengaruhi kepribadian seorang remaja. Lingkungan keluarga merupakan merupakan tempat anak tumbuh dan berkembang akan sangat berpengaruh terhadap kepribadian seorang anak teruatama cara orangtua dalam mendidik dan membesarkan anaknya. Peran orangtua sering kali tanpa dibarengi dengan pemahaman tentang kepribadian yang berakibat pada perilaku negatif pada anaknya (Sjarkawi, 2014).

Penting sekali bagi orangtua untuk memahami bahwa bullying itu sama sekali bukan dari bagian normal dari masa pertumbuhan yang harus dilewati. Tindakan bullying itu berakibat buruk bagi korban, saksi sekaligus bagi pelakunya itu sendiri. Bahkan efeknya terkadang membekas sampai anak telah dewasa sehingga orangtua harus selalu waspada terhadap apa yang mungkin terjadi pada anaknya karena bullying akan tumbuh subur dan sulit diberantas apabila orangtua tidak perduli terhadap hal tersebut (Prayitna, 2010).

Bentuk pola asuh orangtua mempengaruhi pembentukan kepribadian anak saat dia dewasa. Hal ini di karenakan watak seorang individu sebenarnya jauh sebelumnya sudah ditanam tumbuhkan ke dalam jiwa seorang individu sejak sangat awal yaitu pada masa kanak-kanak. Itulah sebabnya pola asuh yang di tetapkan oleh orangtua sangan dominan dalam membentuk kepribadian anak sejak kecil hingga dewasa. Pola asuh yang diterapkan orangtua sangat bervariasi seperti otoriter, demokratis maupun permisif. Hal ini dipengaruhi oleh banyak faktor seperti pendidikan orangtua, pekerjaan, sosial ekonomi, suku/ adat serta fenomena perilaku yang ditunjukkan oleh anak (Djamarah, 2014).

Peran pengasuh atau orang tua murid saat di rumah yang harus bisa menciptakan suasana komunikasi yang baik dengan anaknya dan membekalinya dengan pemahaman spiritual/agama yang cukup dan memberikan contoh ahlakul karimah yang bias dilakukan anak di rumah, karena anak akan meniru orang tua sebagai role model. Pola perilaku ini dapat dirasakan oleh anak dan bisa beri efek negatif maupun positif (Saifurrohman, 2016).

Kejadian bullying banyak terjadi pada remaja usia sekolah 12-17 tahun. SMP Gajah Mada merupakan salah satu SMP di kota Bandar Lampung yang memiliki persepsi kurang baik dari masyarakat. Hal ini disebabkan karena sekolah tersebut merupakan sekolah swasta yang memiliki siswa dengan kenakalan remaja yang cukup tinggi. Perilaku bullying merupakan hal yang sering terjadi pada peserta didik di SMP Gajah Mada Bandar Lampung. Dimana sering terjadi permasalahan peserta didik seperti menyisihkan pergaulan, menyebarkan gosip yang negatif, mengancam, melakukan pemalakan. sehingga butuh penanganan untuk memecahkan masalah peserta didik (Hermansyah, 2017).

Peran perawat dalam menangani atau untuk mengurangi tindakan bullying disekolah yaitu sebagai edukator dan konselor. Perawat ditatanan komunitas harus lebih aktif berperan di sekolah dengan melakukan intervensi melalui pemberian pendidikan kesehatan mengenai bullying sehingga anak dapat mengetahui dampak dari bullying terhadap orang lain dan diri sendiri. Perawat tidak hanya memberikan pelayanan kesehatan secara fisik saja, akan tetapi dapat memberikan pelayanan secara holistic meliputi aspek biopsikososiospiritual pada siswa.

Berdasarkan hasil presurvey yang telah dilakukan pada 3 sekolah SMP swasta di kota Bandar Lampung diperoleh bahwa dari 10 orang yang telah diwawancara dari SMP Gajah Mada terdapat 2 orang (20\%) siswa yang mengatakan pernah mendapat perilaku bullying dari temannya

Anhar Jaya Putra', Teguh Pribadi ${ }^{1 *}$, Dhini Easter Yanti ${ }^{2}$

'Program Studi llmu Keperawatan Fakultas Kedokteran Universitas Malahayati, Bandar Lampung.

${ }^{2}$ Fakultas Kesehatan Masyarakat Universitas Malahayati, Bandar Lampung. Email: easter@gmail.com

Korespondensi Penulis: Teguh Pribadi. *Email: teguh@malahayati.ac.id 
Tipe pola asuh orang tua yang berhubungan dengan perilaku bullying pada pelajar SMP

berupa ejekkan atau olok-olokan tentang bentuk fisik tubuhnya. Selain itu terdapat 3 orang $(30 \%)$ yang mengatakan bahwa pernah melakukan perilaku bullying pada teman dan adik kelasnya dalam bentuk verbal seperti mengejek bentuk fisik dan mengolok-olok didepan umum. Dari 10 orang yang telah diwawancara dari SMP Wiyatama terdapat 2 orang $(20 \%)$ siswa yang mengatakan pernah mendapat perilaku bullying dari temannya berupa ejekkan atau olok-olokan tentang bentuk fisik tubuh dan orangtua. Selain itu terdapat 2 orang $(20 \%)$ yang mengatakan bahwa pernah melakukan perilaku bullying pada teman kelasnya dalam bentuk verbal seperti mengejek bentuk fisik dan memukul teman. Dari 10 orang yang telah diwawancara dari SMP Al Azhar terdapat 1 orang $(10 \%)$ siswa yang mengatakan pernah mendapat perilaku bullying dari temannya berupa ejekkan atau olok-olokan tentang bentuk fisik tubuhnya. Selain itu terdapat 2 orang $(20 \%)$ yang mengatakan bahwa pernah melakukan perilaku bullying pada teman dan adik kelasnya dalam bentuk verbal seperti mengejek bentuk fisik dan mengucilkan teman.

Berdasarkan latar belakang diatas, peneliti merasa penting melakukan penelitian ini agar diperoleh hasil yang lebih akurat dan nyata dengan judul "Hubungan pola asuh orangtua dengan perilaku bullying pada siswa SMP Gajah Mada Kota Bandar Lampung Tahun 2019"

\section{METODE PENELITIAN}

Penelitian kuantitatif dengan rancangan menggunakan analitik dengan pendekatan cross sectional. Penelitian ini sudah lulus kelaikan etik dari Komisi Etik Penelitian Kesehatan (KEPK) Universitas Malahayati dan dilaksanakan di SMP Gajah Mada Kota Bandar Lampung pada Juni 2019. Populasinya seluruh siswa kelas VII dan VIII sebanyak 246 pelajar dengan proportional random sampling di dapatkan sampel sejumlah 153 responden.

Alat pengumpulan data berupa kuesioner untuk mengukur perilaku bullying sebanyak 18 soal dan kuesioner pola asuh orang tua sebanyak 20 soal. Uji validitas 20 butir soal kuesioner tentang pola asuh orang tua diperoleh hasil $r$ hitung $>r$ table yaitu $0,489-0,923$. Sedangkan pada variable perilaku bullying peneliti menggunakan kuesioner sebanyak 30 soal yang berasal dari penelitian sebelumnya diperoleh bahwa $r$ hitung $>r$ table yaitu 0,493-0,914 (Pratama, 2016).

Hasil uji reliabilitas yang dilakukan terhadap 20 butir soal kuesioner tentang pola asuh orangtua diperoleh bahwa $r$ hitung $>r$ table yaitu 0,951. Sedangkan pada variable perilaku bullying peneliti menggunakan kuesioner sebanyak 30 soal yang berasal dari penelitian sebelumnya diperoleh bahwa $r$ hitung $>r$ table yaitu 0,936 . (Pratama, 2016).

Variabel Dependen: perilaku Bullying dengan kriteria berperilaku Bullying, jika skore 76-120 dan Tidak berperilaku Bullying, jika skore 30-75. (Azwar, 2015).

Variabel Independen: Pola Asuh Orang Tua dimana; Otoriter, jika didominasi pola asuh otoriter; Permisif, jika didominasi pola asuh permisif; Involved, jika didominasi pola asuh involved; dan Demokratis, jika didominasi pola asuh demokratis (Baskoro, 2017)

Data diambil dan dikumpulkan langsung dari responden dengan melakuan pengisian kuesioner oleh responden yang dibagikan dan diisi pada hari yang sama. Data dianalisa menggunakan uji chisquare, jika terdapat nilai $p$-value $<0,05$, maka $\mathrm{Ha}$ diterima, begitu juga dengan sebaliknya jika $p$ value $>0,05$, maka Ho ditolak. 
HASIL

Tabel 1. Distribusi Frekuensi Responden $N=153$

\begin{tabular}{lcc}
\hline Variabel & Frekuensi (f) & Persentase (\%) \\
\hline $\begin{array}{l}\text { Jenis Kelamin } \\
\text { Perempuan }\end{array}$ & 73 & \\
Laki-laki & 80 & 57.7 \\
& & \\
Perilaku Bullying Pada Pelajar & & \\
Bullying & 42 & $27.5 \%$ \\
Tidak Bullying & 111 & $72.5 \%$ \\
& & \\
Pola Asuh Orang Tua & & \\
Otoriter & 25 & $16.3 \%$ \\
Permisif & 17 & $11.1 \%$ \\
Diabaikan & 33 & $21.6 \%$ \\
Demokratis & 78 & $51.0 \%$ \\
\hline
\end{tabular}

Berdasarkan tabel 1. dapat diketahui bahwa sebagian besar responden berjenis kelamin laki-laki yaitu sebanyak 80 orang (52.3\%). Responden tidak melakukan perilaku bullying yaitu sebanyak 111 orang $(72.5 \%)$. Responden memiliki pola asuh demokratis yaitu sebanyak 78 orang $(51.0 \%)$.

Tabel 2. Hubungan Pola Asuh Orangtua Dengan Perilaku Bullying N=153

\begin{tabular}{|c|c|c|c|c|c|c|c|}
\hline \multirow{3}{*}{ Pola Asuh Orang Tua } & \multicolumn{4}{|c|}{ Perilaku Bullying Pada Pelajar } & \multirow{2}{*}{\multicolumn{2}{|c|}{ Total }} & \multirow{3}{*}{$p$-value } \\
\hline & \multicolumn{2}{|c|}{ Bullying } & \multicolumn{2}{|c|}{ Tidak Bullying } & & & \\
\hline & $\mathrm{n}$ & $\%$ & $n$ & $\%$ & $\mathbf{N}$ & $\%$ & \\
\hline Otoriter & 10 & 6.5 & 15 & 9.8 & 25 & $16.3 \%$ & \\
\hline Permitif & 7 & 4.6 & 10 & 6.5 & 17 & $11.1 \%$ & \\
\hline Diabaikan & 20 & 13.1 & 13 & 8.5 & 33 & $21.6 \%$ & 0.000 \\
\hline Demokratis & 5 & 3.3 & 73 & 47.7 & 78 & $51.0 \%$ & \\
\hline Total & 42 & 27.5 & 111 & 72.5 & 153 & $100 \%$ & \\
\hline
\end{tabular}

Berdasarkan tabel 2. didapat hasil dari 25 orang yang memiliki pola asuh ototriter, terdapat 10 orang $(6.5 \%)$ yang melakukan bullying sedangkan 15 orang $(9.8 \%)$ tidak melakukan bullying. Dari 17 orang yang memiliki pola asuh permisif, terdapat 7 orang (4.6\%) melakukan bullying sedangkan 10 orang (6.5\%) tidak melakukan bullying. Dari 33 orang yang memiliki pola asuh diabaikan, terdapat 20 orang $(13.1 \%)$ melakukan bullying sedangkan 13 orang (8.5\%) tidak melakukan bullying. Dari 78 orang yang memiliki pola asuh demokratis, terdapat 5 orang (3.3\%) yang melakukan bullying sedangkan 73 orang $(47.7 \%)$ tidak melakukan bullying. Hasil analisa menggunakan chi-square, didapatkan $P$ Value $=0,000$, sehingga $p$-value $<a(0,000<$ $0,05)$ maka Ho ditolak.

\section{PEMBAHASAN}

Berdasarkan hasil penelitian dapat diketahui bahwa sebagian besar responden mengaku tidak pernah melakukan perilaku bullying yaitu sebanyak 111 orang (72,5\%). Berbeda dengan hasil penelitian yang telah dilakukan pada remaja SMK Negeri 1 Manado diperoleh hasil bahwa sebagian besar berperilaku bullying berat dengan $54,2 \%$ (26 responden) sedangkan yang berperilaku bullying ringan sebanyak 22 orang $(45,8 \%)$. Pelajar

Anhar Jaya Putra', Teguh Pribadi*, Dhini Easter Yanti ${ }^{2}$

'Program Studi llmu Keperawatan Fakultas Kedokteran Universitas Malahayati, Bandar Lampung.

${ }^{2}$ Fakultas Kesehatan Masyarakat Universitas Malahayati, Bandar Lampung. Email: easter@gmail.com

Korespondensi Penulis: Teguh Pribadi. *Email: teguh@malahayati.ac.id 
Tipe pola asuh orang tua yang berhubungan dengan perilaku bullying pada pelajar SMP

berperilaku agresif terhadap siswa lainnya dan dilakukan berulang-ulang oleh seorang atau sekelompok siswa yang memiliki kekuasaan, terhadap siswa lain yang lebih lemah dengan tujuan menyakiti orang tersebut (Korua, Kanine, \& Bidjuni, 2015; Ehan (2016). Anak yang melakukan bullying biasanya memiliki sikap hiperaktif, impulsif, kehilangan konsentrasi, dan memiliki pengalaman kekerasan di masa lalu. Pelaku bullying biasanya menyerang orang lain terlebih dahulu sebelum diserang sebagai cara untuk melindungi dirinya (Sufriyani, \& Sari, 2017).

Menurut peneliti adanya remaja yang melakukan bullying disebabkan oleh beberapa faktor dan salah satunya adalah media informasi atau tontonan yang negatif yang sangat mudah di dapatkan seperti video sehingga membentuk role model. Tayangan yang terdapat dalam berbagai media saat ini tanpa disadari telah mempengaruhi pola pikir anak-anak bahwa perilaku bullying merupakan hal yang wajar. Tontonan dari media tersebut yang dianggap lucu karena melakukan perilaku bullying akan ditiru oleh anak-anak karena mereka sudah beranggapan bahwa itu hal yang wajar dan menyenangkan. Selain pengaruh berbagai media, faktor lingkungan juga mempengaruhi perilaku bullying pada remaja. Remaja yang berada pada lingkungan yang memperlihatkan perilaku bullying akan terpapar oleh perilak tersebut baik di lingkungan keluarga, sekolah maupun teman sepermainan.

Berdasarkan hasil penelitian dapat diketahui bahwa sebagian besar responden memiliki pola asuh demokratis yaitu sebanyak 78 orang $(51,0 \%)$. Keluarga adalah lingkunga belajar yang pertama sekali dijumpai anak. Anak mulai mengetahui mana yang benar dan salah adalah dari keluarga terutama orangtua, dalam keluarga pula anak mendapatkan nilai dan norma yang dianut budaya dan keyakinan masyarakat setempat. Oleh karena itu orangtua memegang peran penting dalam pembentukan perilaku anak. Pentransferan nilai dan norma tersebut tidak terlepas dari tipe pola asuh yang diterapkan orangtua pada anak, baik itu pola asuh pemisif, otoriter maupun demokrasi. Setiap pola asuh memberikan andil dalam pembentukan karakter anak. Orangtua seharusnya menerapkan ketiga pola asuh tersebut pada kondisi yang tepat.

Menurut teori pola asuh dimana upaya orangtua yang konsisten dan persisten dalam menjaga dan membimbing anak dari sejak dilahirkan hingga remaja. Pola asuh orangtua adalah pola perilaku yang diterapkan pada anak dan bersifat relatif konsisten dari waktu ke waktu. Pola perilaku ini dapat dirasakan oleh anak dan bisa beri efek negatif maupun positif. Pola asuh orang tua merupakan gambaran tentang sikap dan perilaku orang tua dan anak dalam berinteraksi, berkomunikasi selama mengadakan kegiatan pengasuhan. Dalam kegiatan mernberikan pengasuhan ini, orang tua akan memberikan perhatian, peraturan, disiplin, hadiah dan hukuman, serta tanggapan terhadap keinginan anaknya (Djamarah, 2014).

Berdasarkan hasil penelitian sebelumnya pada remaja di SMP N 4 Gamping Sleman diperoleh hasil bahwa pola asuh orang tua yang paling banyak diterapkan oleh orang tua siswa di SMP N 4 Gamping Sleman adalah pola asuh demokratis yaitu sebanyak 22 orang (33,8\%) (Pratama, 2016). Hasil penelitian ini juga diketahui bahwa sebagian besar responden memiliki pola asuh demokratis. Menurut peneliti hal ini disebabkan karena remaja merasakan mendapat perhatian sekaligus mendapat tanggung jawab dari orangtuanya. Orangtua memberikan kebebasan pada remaja terhadap apa yang akan dilakukan tetapi tetap memberikan batasan untuk mengarahkan remaja agak tepat dalam mengambil keputusan. Banyaknya orangtua yang menerapkan pola asuh demokratis dipengari oleh beberapa faktor seperti tingkat pendidikan serta pengalaman. Orangtua yang memiliki pendidikan yang cukup lebih terbuka terhadap masukan serta pengetahuan yang diberikan. Selain itu pengalaman orangtua juga dapat mempengruhi pola asuh yang akan dia terapkan terhadap anaknya. Orangtua yang sebelumnya mendapatkan pola asuh yang kurang baik biasanya tidak akan menerapkan pola asuh yang sama terhadap anaknya karena mereka sudah merasakan dampak yang kurang baik dari pola asuh tersebut sehingga tidak akan menerapkannya lagi pada anaknya saat ini.

Hasil analisa menggunakan chi-square, didapatkan $p$-value $=0,000$, sehingga $p$-value $<a$ $(0,000<0,05)$ maka Ho ditolak. Jadi dapat disimpulkan terdapat hubungan pola asuh orangtua dengan perilaku bullying pada siswa SMP Gajah Mada Kota Bandar Lampung Tahun 2019. Secara teori penyebab terjadinya bullying dipengaruhi oleh beberapa faktor seperti pola asuh

Anhar Jaya Putra', Teguh Pribadi*', Dhini Easter Yanti ${ }^{2}$

'Program Studi llmu Keperawatan Fakultas Kedokteran Universitas Malahayati, Bandar Lampung.

${ }^{2}$ Fakultas Kesehatan Masyarakat Universitas Malahayati, Bandar Lampung. Email: easter@gmail.com

Korespondensi Penulis: Teguh Pribadi. *Email: teguh@malahayati.ac.id 
Tipe pola asuh orang tua yang berhubungan dengan perilaku bullying pada pelajar SMP

orang tua. Peran pengasuh atau orang tua murid saat di rumah yang harus bisa menciptakan suasana komunikasi yang baik dengan anaknya dan membekalinya dengan pemahaman spiritual/agama yang cukup dan memberikan contoh ahlakul karimah, hal tersebut menjadikan anak akan meniru orang tua sebagai role model. Beberapa ciri-ciri anak yang suka melakukan bullying adalah anak yang mengalami masalah dalam keluarganya, anak yang terlalu dimanja di rumahnya, anak yang ingin mendapat pengakuan dan biasanya kurang dapat perhatian (Saifurrohman, 2016).

Hasil penelitian pada remaja di SMK Cikini, Jakarta diperoleh hasil bahwa berdasarkan hasil uji statistic diperoleh $p$ value 0,001 maka dapat disimpulkan adanya hubungan yang signifikan antara pola asuh ibu dengan perilaku bullying (Annisa, 2012). Dari hasil penelitian ini diketahui bahwa remaja yang melakukan perilaku bullying sebagian besar memiliki pola asuh diabaikan oleh orang tuanya. Menurut peneliti hal ini disebabkan karena remaja tidak mendapatkan perhatian yang cukup dari orang tuanya. Orang tua tidak berperan dengan baik bagi perkembangan psikologis remaja sehingga remaja tidak terarah dalam bersikap dan berperilaku. Remaja yang tidak mendapatkan perhatian serta tanggung jawab dari orangtuanya biasanya akan berperilaku tidak terkontrol karena merasa tidak akan ada yang menghukum atau menegurnya sehingga remaja merasa dapat melakukan apa saja sesuai kemauannya tanpa memikirkan dampaknya kemudian hari.

Keluarga merupakan lingkungan yang terdekat untuk membesarkan dan mendewasakan anak,di dalamnya anak mendapat pendidikan yang pertama kali, oleh karena itu, keluarga memiliki peranan yang penting dalam perkembangan anak, keluarga yang baik akan berpengaruh positif bagi perkembangan anak, sedangkan keluarga yang buruk akan berpengaruh negatif. Dalam penelitian ini menunjukkan adanya hubungan yang signifikan antara keluarga dengan perilaku bullying. Pada orang tua yang mendidik anak secara otoriter dan cenderung memberi hukuman fisik pada anak (dalam setiap pelanggaran atas perilakunya) tanpa memberikan penjelasan, membuat anak menjadi "marah dengan keluarga" dan melakukan pelampiasan di luar rumah salah satunya dengan melakukan bullying.

\section{SIMPULAN}

Sebagian besar responden mengaku tidak melakukan perlakuan bullying terhadap teman sekolahnya sebanyak 111 orang (72,5\%). Sebagian besar responden merasa memiliki pola asuh demokratis dari orang tuanya sebanyak 78 orang $(51,0 \%)$. Didapatkan hubungan pola asuh orangtua dengan perilaku bullying pada siswa SMP Gajah Mada kota Bandar Lampung tahun 2019 dengan nilai $p$-value $<a(0,000<0,05)$.

\section{SARAN}

Hasil penelitian ini dapat menambah informasi dan pengetahuan pada orang tua khususnya mengenai masalah yang terjadi pada anak remaja seperti perilaku bullying di sekolah serta dapat memberikan perhatian yang lebih serta menerapakan pola asuh yang tepat pada anak remaja agar perilaku bullying antar mereka dapat dicegah.

Penelitian ini dapat menjadi sarana dan referensi bagi pihak pendidik/ sekolah dalam mengatasi masalah bullying pada remaja dengan melakukan edukasi dan konseling pada orang tua. Bagi peneliti selanjutnya agar dapat meningkatkan hasil penelitian dengan memperluas subjek penelitian atau dengan mengambil variabel yang belum diteliti dalam penelitian ini.

\section{DAFTAR PUSTAKA}

Alawiyah, M. A. (2018). Peran guru dan lingkungan sosial terhadap tindakan bullying siswa sekolah dasar. Joyful Learning Journal, 7(2), 78-86.

Annisa, A. (2012). Hubungan antara pola asuh ibu dengan perilaku bullying remaja. Diakses dari:

http://lib.ui.ac.id/file?file=digital\%2F20300340S42001-Annisa.pdf

Apsari, F. (2013). Hubungan antara harga diri dan disiplin sekolah dengan perilaku bullying pada remaja (Doctoral dissertation, Universitas Muhammadiyah Surakarta).

Azwar, S. (2015). Sikap dan Perilaku. Dalam: Sikap Manusia Teori dan Pengukurannya, 2, 322. 
Tipe pola asuh orang tua yang berhubungan dengan perilaku bullying pada pelajar SMP

Baskoro,D.S.B.(2017). Menjadi Lebih Baik (Parent Healing), Jakarta: Alex Media Komputindo, 2019

Djamarah, S. B. (2014). Pola asuh orang tua dan komunikasi dalam keluarga. Jakarta: Rineka Cipta

Ehan, E. (2016). Bullying dalam pendidikan. Diakses dari: http://file.upi.edu/Direktori/FIP/jur._pend._luar_ biasa/195707121984032ehan/bullying dalam pendidikan.pdf

Fauzi, R. N. F., \& Mamnu'ah, M. A. (2017). Hubungan pola asuh orang tua dengan perilaku bullying pada remaja di SMP Muhammadiyah 2 Gamping Sleman Yogyakarta (Doctoral dissertation, Universitas' Aisyiyah Yogyakarta).

Hermansyah, A. (2017). Pemberian layanan konseling kelompok dengan teknik role playing untuk mengurangi perilaku bullying pada peserta didik kelas VII DI SMP Gajah Mada Bandar Lampung Tahun Pelajaran 2016/2017(Doctoral dissertation, IAIN Raden Intan Lampung).

Korua, S. F., Kanine, E., \& Bidjuni, H. (2015). Hubungan pola asuh orang tua dengan perilaku bullying pada remaja SMK Negeri 1 Manado. Jurnal keperawatan, 3(2).

Pratama, Y. (2016). Hubungan Pola Asuh Orang Tua dengan Perilaku Bullying Remaja di SMP N 4 Gamping Sleman (Doctoral dissertation, STIKES Jenderal Achmad Yani Yogyakara).
Priyatna, A. (2013). Lets end bullying. Elex Media Komputindo

Saifulrohman M. (2016). Bullying dan remaja. Diakses dari http://www.academia.edu/31101817/bullying d an remaja

Setyawan, D. (2015). KPAl: Pelaku Kekerasan Terhadap Anak Tiap Tahun Meningkat. Diakses dari: http://www.kpai.go.id/berita/kpai-pelakukekerasan-terhadap-anak-tiaptahun-meningkat/

Sjarkawi, P. K. A. (2011). Peran Moral, Intelektual, Emosional, dan Sosial sebagai wujud Integritas Membangun Jati Diri, Jakarta: PT. Bumi Aksara.

Sufriani, S., \& Sari, E. P. (2017). Faktor Yang Mempengaruhi Bullying Pada Anak Usia Sekolah Di Sekolah Dasar Kecamatan Syiah Kuala Banda Aceh. Idea Nursing Journal, 8(3)

Ulfah, W. V., Mahmudah, S., \& Ambarwati, R. M. (2017). Fenomena school bullying yang tak berujung. Intuisi: Jurnal Psikologi IImiah, 9(2), 93-100.

Wardhana, K. (2014). Sudah Dong Stop-Bullying Campaign Buku Panduan Melawan Bullying. 